\title{
STUDY ON THE EFFECTS OF MULTIPLE MATINGS IN Coccinella transversalis FOR ITS BEHAVIOUR AND REPRODUCTION
}

\author{
Mahadev Bista \\ Department of Zoology, Siddhanath Science Campus, Tribhuvan University, Mahendranagar, Nepal \\ Corresponding author: bistamahadev@yahoo.com
}

(Received: January 2, 2019; Revised: March 6, 2019; Final-revised: June 2, Accepted: June 3, 2019)

\begin{abstract}
The evolution and maintenance of multiple mating (repeated mating or polyandry) in predaceous ladybird beetles (Coleoptera: Coccinellidae) is an adaptive puzzle; since a single ejaculate of male often provides enough sperm to female for her lifetime egg production. Despite numerous studies on multiple mating evaluating reproductive attributes, there are negligible studies that investigated changes in behavioural patterns in ladybirds during multiple mating. In the present study, effects of multiple mating on mating behavioural pattern of males and reproductive attributes of females have been assessed using Coccinella transversalis as an experimental ladybird species. Results revealed that during copulation behaviour, time for the commencement of mating, latent period, wriggling movement duration, number of bouts and mating duration decreased with increase in number of mating; whereas interval between successive bouts increased significantly. Moreover, fecundity and egg viability of females increased with increase in number of mating.
\end{abstract}

Keywords: Aphid, Biocontrol, Coccinella transversalis, Ladybirds, Mating

\section{INTRODUCTION}

Multiple mating is a widespread phenomenon in both the male and female insects (Ronkainen et al. 2010, Tuler et al. 2018). However, the evolution and maintenance of multiple mating (repeated mating or polyandry) in females is an adaptive puzzle since females typically obtain all the resources they need from males in only one or a few mating. Multiple mating with one or more than one (polyandry) male within a single breeding season have been reported for a number of insects, including the ladybird beetles (Omkar et al. 2010, Dubey et al. 2018). Multiple mating is associated with numerous benefits that are grouped into direct (non-genetic, material benefit/ first generation) and indirect (genetic/ second generation) benefits (Jennions \& Petrie 2000, Singh et al. 2018).

Direct benefits are derived from the sperm quality of certain males (extra sperm or male derived substances) leading to an increase in female fecundity, longevity or mating rate (Arnqvist \& Nilsson 2000, Bista \& Omkar 2012, Dubey et al. 2018). Additionally, if males transfer insufficient sperm, females may mate multiple times to ensure that all their eggs are fertilized, hence obtaining the fecundity benefits. Thus, multiple mating acts as an insurance against the male infertility, reduce the risk of sperm depletion, eliminate the problems of sperm incompatibility, allow females to select the highest quality sperm, increase genetic variation amongst the offspring, and increase pre-hatching embryo survival (Yasui 1997). As a result, a female can achieve higher fitness either through the production of sons with higher fertilization success due to increased competitiveness/attractiveness ("sexy sons"), or through the production of more genetically viable offspring ("good genes") (Jennions \& Petrie 2000, Xie \& Pang 2016). Indirect benefits of multiple mating, however, are next generation benefits, associated with post copulatory sexual selection mechanisms that are promoted by mating with multiple but genetically variable males (i.e., sperm competition and cryptic choice) (Jennions \& Petrie 2000, Bista \& Omkar 2012, Xie \& Pang 2016). Post copulatory sexual selection can select compatible genes that reduce the inbreeding depression and lead to the production of offspring of higher quality (Yasui 1997, Firman \& Simmons 2012). Although, the direct benefits play a crucial role in the evolutionary origin of multiple mating, over the last few decades there have been an increasing theoretical and empirical evidences in support of the adaptive values of indirect benefits (Arnqvist \& Nilsson 2000, Singh et al. 2018, Tuler et al. 2018).

Despite numerous studies on multiple mating evaluating the reproductive attributes, investigation on the changes in behavioural patterns in ladybird beetles during multiple mating are negligible. In the present study, effects of multiple mating on mating behavioural pattern of males and reproductive attributes of females have been assessed using Coccinella transversalis, an aphidophagous ladybird beetle of the Oriental region, native to India and found mainly in South Asia. It is expected that the results would be helpful for the mass multiplication of this ladybird species in laboratories for the augmentative biocontrol of aphid pests.

\section{MATERIALS AND METHODS}

\section{Establishment of stock}

Adults of $C$. transversalis were collected from the agricultural fields in adjoining areas of Lucknow city and brought into laboratory for establishment of stock in an environmental test chamber (ETC) (CH-6S, Remi Instruments, Mumbai India) maintained at $27 \pm 1^{\circ} \mathrm{C}, 65 \pm 5 \% \mathrm{RH}$ and $14 \mathrm{~L}: 10 \mathrm{D}$ 
photoperiod. Aphid species, Aphis craccivora Koch infested on cowpea (Vigna unguiculata L.) plants maintained in glasshouse $\left(23 \pm 1^{\circ} \mathrm{C} ; 65 \pm 5 \% \mathrm{RH}\right.$ and $14 \mathrm{~L}$ : $10 \mathrm{D}$ photoperiod) was used as the prey along with its host plant twig. Males and females were sexed and paired in Petri dishes $\left(9.0 \times 1.5 \mathrm{~cm}^{2}\right)$. The eggs were collected daily and egg hatching was recorded. The instars were reared in plastic beakers $\left(15.0 \times 12.0 \mathrm{~cm}^{2}\right)$ on daily replenishment of ad libitum supply of $A$. craccivora infested on bean twig. Newly emerged adults were isolated and placed individually in Petri dishes and were used for experimental purpose. Wild stock from fields was added time to time to the laboratory stock to avoid inbreeding.

\section{Experimental design}

To determine the effects of multiple mating on mating behavioural pattern of males and reproductive attributes of females of $C$. transversalis, protocols suggested by Michaud et al. (2013) and Bista \& Omkar (2012) were followed, i.e. 10day old virgin females were paired with 10-day old unmated males and subjected to $1,3,5,7$ or 10 mating (single mating per day). In case of 3 mating, males and females (pairs) were subjected to single mating per day on $10^{\text {th }}, 11^{\text {th }}$ and $12^{\text {th }}$ day. In case of 5 mating, pairs were subjected to single mating per day on $10^{\text {th }}, 11^{\text {th }}, 12^{\text {th }}, 13^{\text {th }}$ and $14^{\text {th }}$ day. Similarly, in case of 7 and 10 matings pairs were subjected to single mating per day from $10^{\text {th }}$ day till $16^{\text {th }}$ and $18^{\text {th }}$ day, respectively. Each pair was kept in Petri dish $\left(9.0 \times 1.5 \mathrm{~cm}^{2}\right)$ with ad libitum A. craccivora as prey infested on cowpea ( $V$. unguiculata). When mating occurred, the behavioural patterns and duration of each event, viz. time taken for commencement of mating, latent period (time from genital contact to start of first stroke), number of strokes (vertical movements), wriggling movement durations, number of bouts (lateral shakings), interval (resting interval between successive bouts) and total mating duration (from genital contact till the end of mating), were observed under stereoscopic binocular microscope at 16X magnification. After requisite number of mating, the females were separated and their daily oviposition (fecundity) and egg viability were recorded for the next 20 days in 10 replicates $(n=10)$.

\section{Statistical analysis}

Data on various mating behaviour (time for commencement of mating, latent period, number of strokes, wriggling movement duration, number of bouts, interval between successive bouts and mating duration) and reproductive attributes (fecundity and egg viability) of males and females of $C$. transversalis were assessed using one-way ANOVA followed by post hoc Tukey's test of comparison. All data were checked for normal distribution using Bartlett's test for normality prior to being subjected to one-way ANOVA. All percent data were subjected to arcsine square root transformation prior to ANOVA. Pearson's correlation coefficient was used to test for correlations between behaviour attributes and number of mating, and between reproductive attributes and number of mating. All analyses were done using the statistical software MINITAB 16 (Minitab Inc., State College, Pennsylvania, USA).

\section{RESULTS}

In the present study, time taken for the commencement of mating $(\mathrm{r}=-0.737 ; \mathrm{P}<0.0001)$, latent period $(\mathrm{r}=-0.868 ; \mathrm{P}<$ $0.0001)$, wriggling movement durations $(\mathrm{r}=-0.364 ; \mathrm{P}=$ $0.009)$, numbers of bouts $(\mathrm{r}=-0.715 ; \mathrm{P}<0.0001)$ and mating durations $(\mathrm{r}=-0.702 ; \mathrm{P}<0.0001)$ decreased significantly with increase in the number of mating; being minimum for the tenth mating and maximum for the first mating. In contrast, the time interval between the successive bouts increased significantly $(r$ $=0.691 ; \mathrm{P}<0.0001)$ from single to ten mating; and the pairs had minimum time interval between the successive bouts for the first mating and maximum for the tenth mating (Table 1). The present study further revealed a significant increase in the fecundity $(\mathrm{r}=0.806 ; \mathrm{P}<0.0001)$ and percent egg viability $(\mathrm{r}=$ $0.811 ; \mathrm{P}<0.0001)$ with increase in the number of mating. Both the fecundity and egg viability were recorded maximum after ten mating and minimum after the single mating (Table $1)$.

Table1. Effect of multiple matings on mating behaviour and reproductive attributes of $C$. transversalis (Values are Mean \pm S.E; * \& ** denote $\mathbf{F}$-values to be significant at $\mathbf{P}<0.05$ and $\mathbf{P}<0.01$, respectively $($ d.f. $=4$, 49); NS denotes $\mathbf{F}$-values to be non significant at $\mathbf{P}>\mathbf{0 . 0 5}$; $\mathbf{a}, \mathbf{a b}, \mathrm{b}$ and $\mathrm{c}$ represent the significant differences amongst the number of mating per mating behavior based on Tukey's post hoc comparison of means)

\begin{tabular}{|c|c|c|c|c|c|c|c|c|}
\hline $\begin{array}{c}\text { Mating } \\
\text { No. }\end{array}$ & $\begin{array}{l}\text { TCM } \odot \\
\text { (second) }\end{array}$ & $\begin{array}{l}\text { Latent } \\
\text { period } \\
\text { (second) }\end{array}$ & $\begin{array}{c}\text { WMD@ } \\
\text { (minute) }\end{array}$ & $\begin{array}{c}\text { Number of } \\
\text { Bouts }\end{array}$ & $\begin{array}{c}\text { Interval } \\
\text { (seconds) }\end{array}$ & $\begin{array}{c}\text { Mating } \\
\text { duration } \\
\text { (minutes) }\end{array}$ & $\begin{array}{l}\text { Fecundity } \\
\text { (No. of eggs) }\end{array}$ & $\begin{array}{c}\text { Egg viability } \\
(\%)\end{array}$ \\
\hline One & $7.70 \pm 0.39^{c}$ & $7.21 \pm 0.26^{\mathrm{c}}$ & $6.30 \pm 0.13^{\mathrm{b}}$ & $186.50 \pm 4.35^{\mathrm{b}}$ & $4.19 \pm 0.14^{\mathrm{a}}$ & $29.10 \pm 0.41^{\mathrm{c}}$ & $795.00 \pm 17.28^{\mathrm{a}}$ & $87.22 \pm 0.25^{\mathrm{a}}$ \\
\hline Three & $5.35 \pm 0.65^{\mathrm{b}}$ & $5.68 \pm 0.17^{b}$ & $6.26 \pm 0.18^{b}$ & $172.40 \pm 6.10^{\mathrm{b}}$ & $4.79 \pm 0.25^{\mathrm{a}}$ & $26.10 \pm 0.54^{\mathrm{b}}$ & $849.00 \pm 25.72^{\mathrm{ab}}$ & $91.04 \pm 0.43^{b}$ \\
\hline Five & $4.50 \pm 0.30^{\mathrm{ab}}$ & $5.63 \pm 0.20^{b}$ & $5.92 \pm 0.15^{\mathrm{a}}$ & $154.10 \pm 5.00^{\mathrm{ab}}$ & $4.89 \pm 0.13^{\mathrm{ab}}$ & $24.90 \pm 0.31^{\mathrm{ab}}$ & $889.00 \pm 13.56^{\mathrm{b}}$ & $91.49 \pm 0.34^{\mathrm{b}}$ \\
\hline Seven & $3.75 \pm 0.28^{\mathrm{a}}$ & $4.11 \pm 0.24^{\mathrm{a}}$ & $5.88 \pm 0.07^{\mathrm{ab}}$ & $148.60 \pm 7.16^{\mathrm{a}}$ & $5.53 \pm 0.25^{\mathrm{b}}$ & $23.20 \pm 1.13^{\mathrm{a}}$ & $941.00 \pm 13.81^{b}$ & $93.49 \pm 0.35^{\mathrm{c}}$ \\
\hline Ten & $3.33 \pm 0.11^{\mathrm{a}}$ & $3.44 \pm 0.18^{\mathrm{a}}$ & $5.78 \pm 0.14^{\mathrm{ab}}$ & $136.30 \pm 4.43^{\mathrm{a}}$ & $5.94 \pm 0.20^{\mathrm{b}}$ & $22.50 \pm 0.80^{\mathrm{a}}$ & $1046.00 \pm 22.28^{c}$ & $94.03 \pm 0.39^{\mathrm{c}}$ \\
\hline F-value & $19.70^{* *}$ & $45.47 * *$ & $3.72 *$ & $12.92 * *$ & $10.99 * *$ & $13.35^{* *}$ & $24.93 * *$ & $56.57 * *$ \\
\hline
\end{tabular}

(C) TCM= Time for commencement of mating \& WMD= Wriggling movement duration 


\section{DISCUSSION}

The present study revealed significant effects of multiple mating on the mating behaviour and reproduction of the ladybird beetle, $C$. transversalis. During the copulation behaviour, time for the commencement of mating, latent period, wriggling movement duration, number of bouts and mating duration decreased, whereas interval between the successive bouts increased with increase in the number of matings. Decrease in the time for the commencement of mating and latent period with increase in number of matings may be due to: (i) the familiarity with the mate, and/or (ii) the mating process. Similar reduction in the time for the commencement of mating with increase in number of matings has also been reported earlier in ladybirds, Coleomegilla maculata (De Geer) (Harmon et al. 2008) and Coelophora saucia (Mulsant) (Omkar et al. 2010). However, the increased latent period before the first mating and its gradual decrease with the consecutive mating has been reported earlier in the ladybird species, Coccinella septempunctata (L.) (Bista \& Omkar 2012).

Longest mating duration and maximum body movements during the first mating indicate that insemination probably takes more time, which could be attributed to: (1) the higher amount of seminal fluid available during the first mating, (2) young age of adults in this study, and/or (3) newness of the mating act. On the other hand, the reduced body movement, shorter mating duration and increase in interval between the successive bouts during the subsequent mating may be attributed to male exhaustion and probably the decreased seminal content (Elzinga et al. 2011; Singh et al. 2018). Similar results have also been reported earlier in ladybirds, $C$. septempunctata by Bista and Omkar (2012) and Tenuisvalvae notata (Mulsant) by Tuler et al. (2018). Contrary to these findings an increase in mating duration with increased number of mating has been reported earlier in the ladybird, Anegleis cardoni (Weise) (Sahu 2012).

Fecundity and egg viability of $C$. transversalis females increased with increase in number of mating. The increased fecundity of multiply mated females is possibly due to the receipt of greater quantities of fecundity stimulants and the nutrients in the male ejaculate which are both stimulatory and nutritional (Xu \& Wang 2011, Colares et al. 2015, Xie \& Pang 2016). A single mating may not provide sufficient stimulants, hormones and/ or nutrients to facilitate maturation and oviposition of entire eggs in ovarioles (Tseng et al. 2007). Further, augmentation in percent egg viability after multiple mating may be attributed to increased amount of sperm available to females for both the immediate utilization and storage (Sahu 2012, Bista \& Omkar 2012). Possibly due to rapid sperm degeneration, multiple mating may serve to provide a female with an adequate supply of fresh sperm for fertilizing all her eggs. In contrast, multiple mating did not result in improved reproductive performance in ladybirds, Adalia bipunctata L. (Perry \& Rowe 2008, Tuler et al. 2018).

\section{CONCLUSION}

Males and females of $C$. transversalis that mated ten times have greater mating behavioural patterns and reproductive success in terms of higher fecundity and egg viability than the singly mated females. Such findings may be utilized for the fast production of this ladybird species in the laboratory for their use in the augmentative biocontrol of insect pests. Further, field based studies needs to validate the present findings. Similar studies may further be designed targeting other ladybird species and a wide range of aphid prey.

\section{ACKNOWLEDGEMENTS}

The author is thankful to Prof. Omkar and Department of Higher Education, Government of Uttar Pradesh, India for financial assistance under Centre of Excellence Programme.

\section{REFERENCES}

Arnqvist, G. and Nilsson, T. 2000. The evolution of polyandry: multiple matings and female fitness in insects. Animal Behaviour 60: 145-164.

Bista, M. and Omkar 2012. Impact of multiple mating on behavioural patterns and reproductive attributes of seven spotted ladybird beetle, Coccinella septempunctata (L.). Journal of Applied Bioscience 38(2): 159-164.

Colares, F., Michaud, J.P., Torres, J.B. and Silva-Torres, C.S. 2015. Polyandry and male mating history affect the reproductive performance of Eriopis connexa (Coleoptera: Coccinellidae). Annals of the Entomological Society of America 108: 736-742.

Dubey, A., Saxena, S. and Mishra, G. 2018. Mating experience influences mate choice and reproductive output in an aphidophagous ladybird. Menochilus sexmaculatus. Animal Biology 68: 247-263.

Elzinga, J., Chevasco, V. Graputo, A. and Mappes, J. 2011. Influence of male mating history on female reproductive success among monandrous Naryciinae (Lepidoptera: Psychidae). Ecological Entomology 36: 170-180.

Firman, R.C. and Simmons, L.W. 2012. Male house mice evolving with post-copulatory sexual selection sire embryos with increased viability. Ecological Letters 15: $42-46$

Harmon, J.P., Hayden, A. and Andow, W. 2008. Absence makes the heart grow fonder: Isolation enhances the frequency of mating in Coleomegilla maculata (Coleoptera: Coccinellidae). Journal of Insect Behavior 21: 495-504.

Jennions, M.D. and Petrie, M. 2000. Why do females mate multiply? A review of the genetic benefits. Biological Reviews 75: 21-64. 
Michaud, J.P., Bista, M., Mishra, G. and Singh, O. 2013. Sexual activity diminishes male virility in two Coccinella species: consequences for female fertility and progeny development. Bulletin of entomological research 103: 570-577.

Omkar, Singh, S.K. and Mishra, G. 2010. Multiple matings affect the reproductive performance of the aphidophagous ladybird beetle, Coelophora saucia (Coleoptera: Coccinellidae). European Journal Entomology 107: 177-182.

Perry, J.C. and Rowe, L. 2008. Neither mating rate nor spermatophore feeding influences longevity in a ladybird beetle. Ethology 114: 504-511.

Ronkainen, K., Kaitala, A. and Kivela, S.M. 2010. Polyandry, multiple mating, and female fitness in a water strider Aquarius paludum. Behavioural Ecology and Sociobiology 64: 657-664.

Sahu, J. 2012. Reproductive attributes of a ladybird beetle, Anegleis cardoni (Weise) (Coleoptera: Coccinellidae). PhD Thesis, University of Lucknow, India.

Singh, P., Mishra, G. and Omkar, O. 2018. Influence of body size and familiarity on mating and reproductive parameters in Menochilus sexmaculatus (Coleoptera: Coccinellidae). Canadian Journal of Zoology 97(5): 453-563.

Tseng, H., Yang, R., Lin, C. and Horng, S. 2007. The function of multiple matings in oviposition and egg maturation in the seed beetle, Callosobruchus maculatus. Physiological Entomology 32:150-156.

Túler, A.C., Silva-Torres, C.S.A., Torres, J.B., Moraes, R.B. and Rodrigues, A.R.S. 2018. Mating system, age, and reproductive performance in Tenuisvalvae notata, a long-lived ladybird beetle. Bulletin of entomological research 108: 616-624.

Xie, J. and Pang, H. 2016. Research of sexual behaviour and evolutionary mechanism of ladybird beetles (Coleoptera: Coccinellidae). Journal of Environmental Entomology 38: 228-237.

Xu, J. and Wang, Q. 2011. Seminal fluid reduces female longevity and stimulates egg production and sperm trigger oviposition in a moth. Journal of Insect Physiology 57(3): 385-390.

Yasui, Y. 1997. A good sperm model can explain the evolution of costly, multiple mating by females. The American Naturalist 149: 573-584. 